\title{
PENGARUH PENAMBAHAN SEMEN TERHADAP KUAT TEKAN BEBAS TANAH LEMPUNG PADA KOTA SORONG
}

\author{
Nurul Puteri H. Matdoan \\ Program Studi Teknik Sipil Universitas Muhammadiyah Sorong \\ Jalan Pendidikan No 27 Kota Sorong, Propinsi Papua Barat \\ Email : puterimatdoan@gmail.com
}

\begin{abstract}
ABSTRAK
Dalam setiap pembangunan, hal utama yang wajib untuk diteliti yaitu tanah. Setiap lokasi memiliki jenis tanah yang berbeda-beda. Seperti halnya yang terjadi di daerah Kota Sorong dimana sering sekali ditemukan jalan yang rusak. Maka untuk membangun infrastruktur dengan spesifikasi tertentu dihadapkan dengan dua alternatif, yaitu dengan stabilisasi tanah atau perbaikan tanah. Uji kuat tekan bebas (Unconfined Compression Test) merupakan cara yang dilakukan di laboratorium untuk menghitung kekuatan geser tanah. Salahsatu kondisi tanah yang kurang baik terdapat di KM. 13 Sekitar United Tractor Kota Sorong. Hal ini dapat terlihat dari kondisi jalan yang dibangun di daerah tersebut dengan mudah mengalami kerusakan. Pada saat musim kemarau tanah di daerah tersebut menjadi sangat keras sedangkan pada musim penghujan menjadi sangat lengket dan becek. Dari latar belakang tersebut penulis menganggap perlu melakukan penelitian, dengan judul "PENGARUH PENAMBAHAN SEMEN TERHADAP KUAT TEKAN BEBAS TANAH LEMPUNG STUDI KASUS KM. 13 SEKITAR UNITED TRACTOR KOTA SORONG". Tujuan penelitian ini yaitu untuk mengidentifikasi karakteristik tanah asli, mengidentifikasi karakteristik tanah setelah di stabilisasi dengan campuran semen 2\%, 4\%,6\%, 8\%, dan 10\% dan mengetahui pengaruh penambahan semen pada tanah lempung terhadap kuat tekan bebas. Metode penelitian yang digunakan adalah dengan melakukan pengambilan sampel tanah secara langsung di lokasi tersebut.
\end{abstract}

Kata Kunci : tanah; stabilisasi tanah; kuat tekan bebas

\section{PENDAHULUAN}

Dalam setiap pembangunan, hal utama yang wajib untuk diteliti yaitu tanah. Setiap lokasi memiliki jenis tanah yang berbeda-beda. Seperti halnya yang terjadi di daerah Kota Sorong dimana sering sekali ditemukan jalan yang rusak. Maka untuk membangun infrastruktur dengan spesifikasi tertentu dihadapkann dengan dua alternatif, yaitu dengan stabilisasi tanah atau perbaikan tanah. Tanah lempung adalah tanah yang mempunyai partikel-partikel tertentu yang menghasilkan sifat-sifat plastisitas pada tanah bila dicampur dengan air. Hal ini ditinjau dari beberapa peneliti terdahulu yang sudah meneliti di daerah tersebut dimana lebih dominan memiliki jenis tanah lempung. Jenis tanah lempung memiliki jenis tanah yang apabila di daerah tersebut akan dibangun sebuah proyek, maka perlu dilakukan stabilisasi tanah. Apabila tidak dilakukannya stabilisasi tanah, maka bisa mengakibatkan terjadinya kerusakan pada konstruksi di atasnya. Uji kuat tekan bebas (Unconfined Compression Test) merupakan cara yang dilakukan di laboratorium untuk menghitung kekuatan geser tanah. Uji kuat ini mengukur seberapa kuat tanah menerima kuat tekan yang diberikan sampai tanah tersebut terpisah dari butiran-butirannya juga mengukur regangan tanah akibat tekanan tersebut. Salahsatu kondisi tanah yang kurang baik terdapat di KM. 13 Depan United Tractor Kota Sorong. Hal ini dapat terlihat dari kondisi jalan yang dibangun di daerah tersebut dengan mudah mengalami kerusakan seperti jalan berlubang dan bergelombang. Pada saat musim kemarau tanah di daerah tersebut menjadi sangat keras sedangkan pada musim penghujan menjadi sangat lengket dan becek. Dan pada konstruksi bangunan mengakibatkan elevasi lantai bangunan yang tidak merata dan keretakan pada dinding bangunan sehingga tidak dapat berdiri dengan kokoh. 
Uji tekan bebas ini dilakukan pada contoh tanah asli dan contoh tanah tidak asli untuk mengukur kemampuannya terhadap kuat tekan bebas. Dari nilai kuat tekan maksimum yang dapat diterima pada masing-masing contoh akan didapat sensivisitas tanah. Nilai sensivisitas ini mengukur bagaimana perilaku tanah jika terjadi gangguan yang diberikan dari luar. Untuk menambah kuat tekan bebas tanah, dalam penelitian ini bahan stabilisasi tanah lempung dengan bahan tambah semen. Semen merupakan stabilizing agent yang baik sekali, karena kemampuannya mengeras dan mengikat butir-butir agregat. Semen juga dapat meningkatkan kekuatan tanah. Kekuatan tanah akan meningkat dengan bertambahnya waktu pemeraman (curing). Dari latar belakang tersebut penulis menganggap perlu melakukan penelitian, dengan judul "PENGARUH PENAMBAHAN SEMEN TERHADAP KUAT TEKAN BEBAS TANAH LEMPUNG STUDI KASUS KM. 13 DEPAN UNITED TRACTOR KOTA SORONG”. Penelitian ini bertujuan untuk mengidentifikasi karakteristik tanah asli, mengidentifikasi karakteristik tanah setelah di stabilisasi dengan campuran semen $2 \%, 4 \%, 6 \%, 8 \%$, dan $10 \%$ dan mengetahui pengaruh penambahan semen pada tanah lempung terhadap kuat tekan bebas..

\section{STATE OF THE ART}

Adapun penelitian terdahulu yang terkait dengan penelitian ini adalah sebagai berikut :

1. Fadilla N., \& Roesyanto (2014) yang meneliti tentang "PENGUJIAN KUAT TEKAN BEBAS (UNCONFINED COMPRESSION TEST) PADA STABILITAS TANAH LEMPUNG DENGAN CAMPURAN SEMEN DAN ABU SEKAM PADI". Mereka mendapatkan bahwa;

1. Dari uji Kuat Tekan Bebas (Unconfined Compression Test) yang dilakukan pada tanah asli diperoleh nilai kuat tekan tanah (qu) sebesar $2,88 \mathrm{~kg} / \mathrm{cm}^{2}$, sedangkan pada tanah remoulded diperoleh nilai kuat tekan tanah (qu) sebesar $0,69 \mathrm{~kg} / \mathrm{cm}^{2}$.Proses stabilisasi yang dilakukan pada berbagai variasi abu sekam padi diperoleh kesimpulan bahwa material abu sekam padi hanya efektif berfungsi pada variasi campuran $2 \%$ PC $+3 \%$ ASP dan 2\% PC $+4 \%$ ASP untuk memperbaiki sifat-sifat tanah dan meningkatkan daya dukung tanah yang distabilisasi, yaitu dengan nilai kuat tekan tanah sebesar $3,82 \mathrm{~kg} / \mathrm{cm}^{2}$ dan $3,64 \mathrm{~kg} / \mathrm{cm}^{2}$. Semakin banyak kadar abu sekam padi yang digunakan, daya dukung akan terus mengalami penurunan.

2. Dari segi kekuatannya, abu sekam padi memiliki karakteristik yang sama dengan abu cangkang sawit (Sinaga, 2014), dimana semakin banyak kadar abu yang ditambahkan justru akan menurunkan daya dukungnya. Hanya abu ampas tebu yang berkekuatan lebih baik (Rezki, 2014).

3. Dari penelitian Rezki (2014), penggunaan abu ampas tebu sebagai bahan stabilisasi menghasilkan penurunan nilai LL, PL, IP dan Wopt dan peningkatan kuat geser tanah lempung.

4. Proses stabilisasi dengan semen dan abu sekam padi ini belum pernah diaplikasikan di lapangan terutama untuk proyek jalan raya.

5. Ada kesulitan dalam proses pengerjaan jika ingin diterapkan di lapangan, yaitu ketersediaan bahan abu sekam padi akan menemui kesulitan karena petani akan mengambil bagian-bagian dari padi untuk dimanfaatkan sebagai pupuk.

6. Dari segi kekuatan yang dihasilkan bahan tambah abu sekam padi dalam pengujian ini tidak terlalu memberikan keuntungan yang besar untuk penerapan di lapangan.

2. Menurut Suyadi, Nababan, \& Sulo (2016) yang meneliti tentang "Studi Eksperimental Kuat Tekan Bebas Tanah Lempung Yang Distabilisasi Dengan Semen Dan Serat Fiber" menyebutkan hasil penelitiannya yaitu;

1. Tanah dasar pada ruas jalan Kudamati - Tujuh Wali-Wali merupakan tanah lempung karena menurut AASHTO termasuk dalam kelompok A-7-5, dan menurut Unified termasuk dalam kelompok CH yaitu lempung tak organik dengan plastisitas tinggi lempung gemuk (fat clay). Nilai kuat tekan bebas tanah dasar pada lokasi penelitian sebesar $0,983 \mathrm{~kg} / \mathrm{cm} 2$.

2. Nilai kuat tekan bebas tanah lempung yang di stabilisasi dengan semen, untuk penambahan kadar semen 
$5 \%, 10 \%$, dan $15 \%$, nilai kuat tekan bebas maksimum sebesar 4,45 kg/cm2, 7,80 kg/cm2, dan13,40 $\mathrm{kg} / \mathrm{cm} 2$. Untuk penambahan $5 \%, 10 \%$, dan $15 \%$, kadar semen dan serat fiber nilai kuat tekan bebas maksimum sebesar4,02 kg/cm2, 7,17 kg/cm2dan $10,09 \mathrm{~kg} / \mathrm{cm} 2$.

3. Tanah lempung yang distabilisasi dengan semen dan serat fiber dapat mempengaruhi nilai kuat tekan bebas secara signifikan. Kenaikan paling signifikan terjadi pada campuran 15\% semen sebesar764,52\%, dan campuran $15 \%$ semen dan serat fiber sebesar 550,97\% dari nilai kuat tekan bebas tanah asli. Semen yang ditambahkan dapat mempengaruhi sifat tanah menjadi getas, dengan adanya penambahan serat fiber dapat mengubah pola keruntuhan yang terjadi, serat fiber mampu bekerja sebagai tulangan mikro pada tanah, yang dapat dan mereduksi keruntuhan pada tanah yang getas.

3. Menurut Raharmadi B. (2017) yang meneliti tentang "MENINGKATKAN NILAI KUAT TEKAN BEBAS (UCS) TANAH MANYAWANG DISTABILISASI DENGAN SEMEN” bahwa hasil yang didapatkan yaitu;

1. Uji distribusi ukuran butir tanah quari dusun Manyawang memenuhi persyaratan yang diijinkan

2. Indeks plastisitas tanah quari Manyawang memenuhi syarat yang diijinkan sebagai material stabilisasi tanah semen yaitu $6,21 \% \leq 10 \%$ (Hicks,2002) dan klasifikasi tanah sistem USCS termasuk pada kelompok CL-ML yaitu lanau tak organik, lempung kepasiran dengan plastisitas rendah dan AASHTO termasuk pada kelompok A-4 yaitu lempung lanau dengan plastisitas rendah.

3. Berat isi kering maksimum (ydmax) dari tanah1,855 t/m3, setelah distabilisasi dengan semen meningkat menjadi 1,858 t/m3, 1,860 t/m3, 1,863 t/m3, 1,872 t/m3, 1,883 t/m3, dan kadar air optimum (Wopt) dari tanah 13,0\% menjadi Wopt $12,5 \%, 11,8 \%, 11,6 \%, 11,5 \%$, dan $11,0 \%$.

4. Nilai UCS tanah Manyawang 3,524\%, setelah distabilisasi dengan semen meningkat menjadi 18,16 $\mathrm{kg} / \mathrm{cm} 2,23,82 \mathrm{~kg} / \mathrm{cm} 2,33,80 \mathrm{~kg} / \mathrm{cm} 2,44,05 \mathrm{~kg} / \mathrm{cm} 2$, dan $46,52 \mathrm{~kg} / \mathrm{cm} 2$, seiring dengan bertambahnya kadar semen.

5. Dan dengan UCSopt $24 \mathrm{~kg} / \mathrm{cm} 2$ didapat PCopt5,8\%, ydmax1,859 t/m3dan Wopt12,1\%.

\section{METODE PENELITIAN}

Penelitian ini dilakukan pada sampel tanah yang tidak diberikan bahan stabilisasi dan pada tanah yang distabilisasi dengan bahan tambah semen dengan variasi yang telah ditentukan

Semua metode penulisan dan analisa dalam artikel ilmiah ini merujuk pada panduan penulisan tugas akhir Fakultas Teknik Universitas Muhammadiyah Sorong tahun 2014 (Pristianto, Amri, \& Rusdi, 2014).

\section{DAFTAR PUSTAKA}

Fadilla, N., \& Roesyanto (2017). PENGUJIAN KUAT TEKAN BEBAS (UNCONFINED COMPRESSION TEST) PADA STABILITAS TANAH LEMPUNG DENGAN CAMPURAN SEMEN DAN ABU SEKAM PADI

Raharmadi, B. (2017). MENINGKATKAN NILAI KUAT TEKAN BEBAS (UCS) TANAH MANYAWANG DISTABILISASI DENGAN SEMEN

Suyadi., Nababan, d, s., \& Sulo, y, k. (2016) STUDI EKSPERIMENTAL KUAT TEKAN BEBAS TANAH LEMPUNG YANG DISTABILISASI DENGAN SEMEN DAN SERAT FIBER

Hardiyatmo. H. C, (2002). Mekanika Tanah 1 Edisi ke-tiga, Universitas Gadjah Mada, Yogyakarta. 
Hardiyatmo. H. C, (2010). Stabilitas Tanah Untuk Perkerasan Jalan, Universitas Gadjah Mada, Yogyakarta.

Pristianto, H., Amri, I., \& Rusdi, A. (2014, May 9). Pedoman Penulisan Tugas Akhir Fakultas Teknik Universitas Muhammadiyah Sorong 2014. http://doi.org/10.17605/OSF.IO/4VTJM.

SNI Revisi Dari 03 - 1964 - 1990 Ke 1964 - 2008 Metode Pengujian Berat Jenis Tanah.

SNI Revisi Dari 03 - 1965 - 1990Ke 1965 - 2008 Metode pengujian Kadar Air.

SNI Revisi Dari 03 - 1966 - 1990 Ke 1966 - 2008 Metode Pengujian Batas plastis.

SNI Revisi Dari 03 - 1967 - 1990 Ke 1967 - 2008 Metode Pengujian Batas Cair Dengan Alat Cassagrande.

SNI Revisi Dari 03 - 3423 - 1994 Ke 3423 - 2008 Metode pengujian Analisis Ukuran Butir Tanah Dengan Alat Hidrometer. 